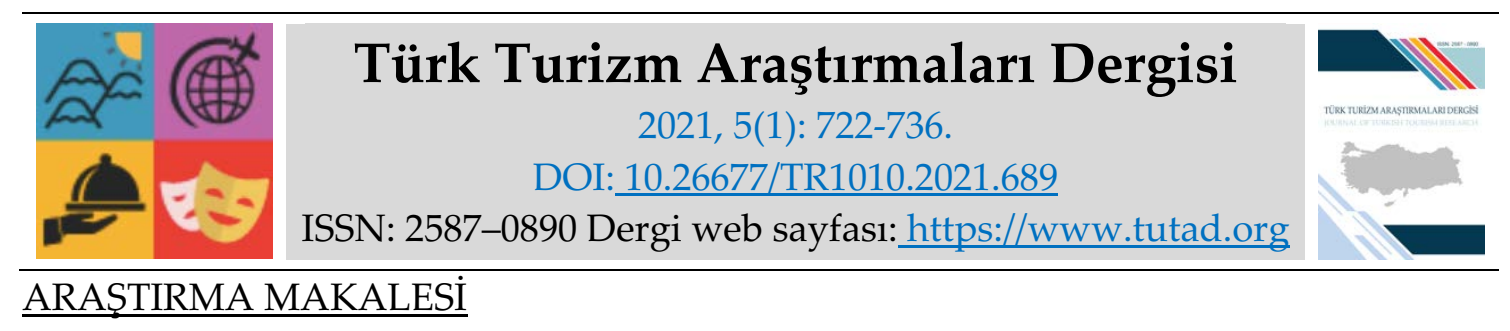

\title{
Yiyecek İşletmeleri Web Sitelerindeki Görsel İçeriklerin Belirlenmesine Yönelik Bir Araştırma
}

Doç. Dr. Hilmi Rafet YÜNCÜ, Anadolu Üniversitesi, Turizm Fakültesi, Eskişehir, e-posta: hryuncu@anadolu.edu.tr

ORCID: https://orcid.org/0000-0002-2876-004X

Prof. Dr. Rıdvan EKMEKÇİ, Pamukkale Üniversitesi, Spor Bilimleri Fakültesi, Denizli, e-posta: rekmekci@pau.edu.tr

ORCID: https://orcid.org/0000-0001-5085-5988

Öğr. Gör. Erhan BABAÇ, Afyon Kocatepe Üniversitesi, Emirdağ MYO, Afyonkarahisar, e-posta: ebabac@aku.edu.tr

ORCID: https://orcid.org/0000-0001-9232-9177

Öz

Dijital dönüşüm ile birlikte pazarlama stratejilerinde çok yönlü uygulamalar ön plana çıkmaktadır. Günümüzde yiyecek işletmelerinin kullanım sıklığının artması, çok yönlü uygulamaların başarısından kaynaklanmaktadır. Yiyecek işletmelerinin web siteleri pazarlama açısından oldukça önemlidir. İlgili literatüre göre bu web sitelerinin görsel içerik maddelerini dört temel başlık altında toplamak mümkündür; renkler, tipografi, yapı ve görsel objeler. Bu araştırmanın çıkış noktasını oluşturan bu durum ile dünyanın en çok tercih edilen dört yiyecek işletmesinin web sitesi içerik analizi yöntemiyle incelenmiştir. Bu web sitelerindeki ortalama kalış süreleri, web sayfalarının ortalama görüntülenme sayısı, web sitelerindeki toplam kelime sayıları ve hiper-metin özellikleri tespit edilmiş; görsel içerikler ise literatürden çıkarılan dört ana madde ve alt maddeleri olan 36 madde ile araştırmanın temaları olarak kabul edilmiş ve bu temalara göre bir kontrol listesi oluşturularak kodlamaları yapılmıştır. Araştırmadan elde edilen bulgulara göre dört websitesinin; beyaz alan kullanımı, kırmızı-siyah, mavi-yeşil renk bileşimlerinin kullanımı, farklı puntoların kullanımı ve sayfalarında ana mesaj kullanımı gibi görsel içerik maddelerini uyguladıkları tespit edilmiştir.

Anahtar Kelimeler: Yiyecek İşletmeleri, Website, Görsel İçerik, İçerik Analizi.

Makale Gönderme Tarihi: 30.12.2020

Makale Kabul Tarihi: 09.03.2021

\section{Önerilen Atıf:}

Yüncü, H. R., Ekmekçi, R. ve Babaç, E. (2021). Yiyecek İşletmeleri Web Sitelerindeki Görsel İçeriklerin Belirlenmesine Yönelik Bir Araştırma, Türk Turizm Araştırmaları Dergisi, 5(1): 722-736. (C) 2021 Türk Turizm Araştırmaları Dergisi. 


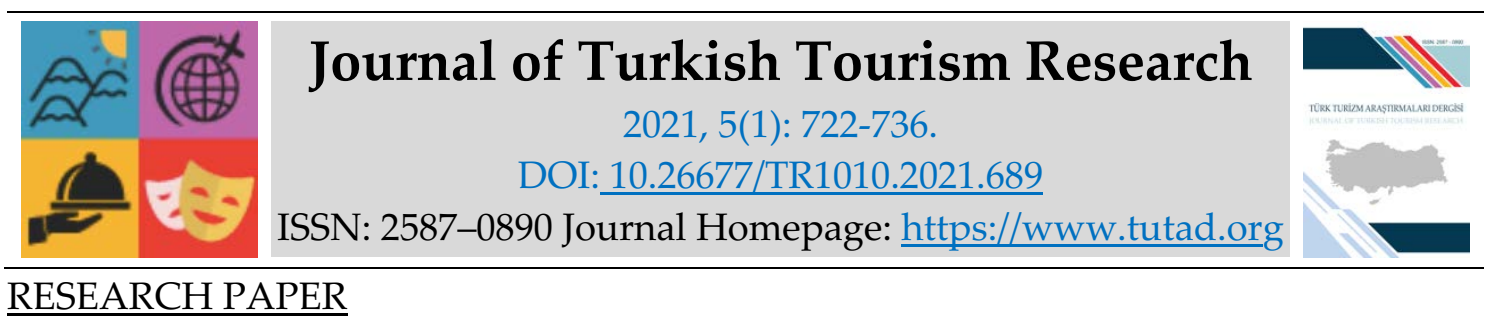

\title{
A Research on The Determination of Visual Content on Food Business Websites
}

Associate Prof. Dr. Hilmi Rafet YÜNCÜ, Anadolu University, Faculty of Tourism, Eskişehir, email: hryuncu@anadolu.edu.tr

ORCID: https://orcid.org/0000-0002-2876-004X

Prof. Dr. Rıdvan EKMEKÇİ, Pamukkale University, Sports Science Faculty, Denizli, e-mail: rekmekci@pau.edu.tr

ORCID: https://orcid.org/0000-0001-5085-5988

Lecturer Erhan BABAÇ, Afyon Kocatepe University, Emirdağ Vocational School, Afyonkarahisar, e-mail: ebabac@aku.edu.tr

ORCID: https://orcid.org/0000-0001-9232-9177

\begin{abstract}
Versatile applications in digital conversion along with marketing strategies come to the fore. The increasing frequency of use of food establishments today is due to the success of versatile applications. Websites of food businesses are very important for marketing. According to the related literature, it is possible to gather the visual content of these websites under four main headings; colors, typography, structure and visual objects. With this situation, which constitutes the starting point of this research, the website of the four most preferred food companies in the world was analyzed by content analysis method. The average length of stay on these websites, the average number of views of the web pages, the total number of words on the websites and hyper-text features were determined; visual content was accepted as the themes of the research with 4 main items and 36 items with sub-items extracted from the literature, and a checklist was created and coded according to these themes. According to the findings of four websites obtained from the research; it was determined that they applied visual content items such as the use of white space, the use of red-black, blue-green color combinations, the use of different fonts and the use of main messages on their pages.
\end{abstract}

Keywords: Food Businesses, Website, Visual Content, Content Analysis.

Received: 30.12 .2020

Accepted: 09.03.2021

\section{Suggested Citation:}

Yüncü, H. R., Ekmekçi, R. and Babaç, E. (2021). A Research on The Determination of Visual Content on Food Business Websites, Journal of Turkish Tourism Research, 5(1): 722-736.

(C) 2021 Türk Turizm Araştırmaları Dergisi. 


\section{Gíriş}

Günümüzde yiyecek işletmelerinin en önemli pazarlama araçlarından biri olan web tabanlı pazarlama araçları sayesinde müşterilere sunulan hizmetin çeşitliliğinin arttığı bilinmektedir. Bu çeşitliliği maksimum düzeyde verimli yöntemlerle sağlamak için müşterilere verilecek mesajların doğru bir planlamayla seçilmesi gerekmektedir. Bu mesajları doğru bir şekilde belirleyebilmek ise belli başlı deneyimlerin değerlendirilmesiyle ortaya çıkarılabilir. Bu deneyimlerin en başında gelen ve bir websitesinin kullanıcı deneyimlerini oluşturan görsel içerikler, o websitesinin kullanılabilirliğini yükselten önemli bir konumdadır. Görsel içerikleri doğru bir konumda yönetmek ise o websitesinin müşteri üzerinden alacağı verimi yükseltebilir niteliktedir. Geleneksel bir imaja sahip olan yiyecek ve içecek endüstrisi, dijital gelişmelere ayak uyduran ve bunu şirketleri için avantaja çeviren güncel odaklı endüstriye dönüşmüştür (Sana Commerce, 2017). Müşterilerin her geçen gün daha fazla mobilleşmesi ve dijital dünyaya olan bağlılığının artması ile gelecekte yiyecek içecek işletmelerinde web tabanlı faaliyetler kaçınılmaz olmuştur.

Günümüzde sürekli gelişen teknoloji ve tasarıma yönelik olarak ortaya çıkan etmenlerin etkisiyle, websitelerin eskiye göre görünüm ve içeriklerinin sergilenme şeklinin nasıl değiştiği görülmektedir (Weichbroth vd., 2016: 1681). Bir websitesinde maksimum düzeyde performans1 arttırmak için kullanılması gereken temel özelliklerin yanında, müşteri odaklı içeriklere yönelik bazı özelliklere de yer verilmelidir. Özellikle son yıllarda tüm dünyada ortaya çıkan salgın ve pandemi süreciyle birlikte çevrimiçi faaliyetlere yönelen insanların, eskiye göre var olan beklentileri de değişmiştir. İçerik planlaması yapılmamış, müşterilere iyi bir kullanıcı deneyimi sağlamayan websitelerin bu beklentileri karşılaması mümkün olmayabilir. Salgınla birlikte ortaya çıkan psikolojik satın alma davranışı, yiyecek işletmelerini evlere taşımıştır. Fiziki olarak yürütülen tüm süreçlerin dijitale dönmesiyle birlikte işletmeler hizmet anlayışlarını dijital kanallar üzerinden yürütmek zorundadır. Pandemi sonrası ortaya çıkacak olan ve salgın sürecinde kazanılan tüm alışkanlıklar, artık dijitalleşen dünyanın en temel adımlarını yeni alışkanlıklara çevirecektir. Bu amaçla, özellikle hizmet sektörünün en önemli kolunu oluşturan yiyecek işletmelerinin websiteleri üzerinden yürüteceği hizmetler, geleceğin sektörel bakış açısını değiştirebilir ve geliştirebilir niteliktedir.

$\mathrm{Bu}$ araştırmanın çıkış noktasını oluşturan bu durum ile dünyanın en çok tercih edilen dört yiyecek işletmesinin web sitelerinin görsel içerikleri içerik analizi yöntemiyle incelenmiştir. Araştırmanın, websitelerde verimli bir şekilde kullanılması gereken görsel içeriklerle ilgili planlama ve konumlandırma konusunda ilgili literatüre katkı sağlayacağı düşünülmektedir.

\section{LITERATÜR}

Bir web sitesinde kullanıcılara yönelik planlanmış ve doğru kullanılan bir arayüz ile kullanıcıların ziyaret sıklıklarını etkileyen en önemli iki faktörden biri olan kullanım kolaylığı ve hız özelliği ile kullanıcı deneyim performansını arttırabilmek mümkün olabilmektedir. Web sitelerinde doğru bir arayüz ile etkileşim sağlamanın en önemli kuralları ise (Fırlar ve Özdem, 2013: 5-6); görsel içerikler, sunum, dolaşım, doğrudan işleme, kullanıcı kontrolü, ipuçları ve uyarı, affedici uyarılar, estetik özellikler, tutarlılık olarak belirlenmiştir.

Web sitesinin kuruluş aşamasında denge, ritim, baskınlık, bütünlük, oran ve eksikleri tamamlama özellikleri önemlidir (Bilgilier, 2016: 715-716). Bu özellikler ile kullanıcı deneyim performansı arttırabilmek, daha verimli bir kuruluş altyapısı oluşturulabilmek için önemlidir.

Turizmde web sitelerinin işlevsel olmasını sağlayan temel özellikler ile ilgili yapılan araştırmalar (Murphy vd., 1996: 75; Azaltun, 2000: 23-43; Palmer ve McCole, 2000: 199-200; Tierney, 2000: 215- 
219; Yayl1, 2000: 36-40; Coleman, 2010; Bonnardel, 2011; Dasgupta ve Utkarsh, 2014; Oyibo ve Vassileva, 2020), ilgili web sitelerinde bulunması gereken bazı maddeler üzerinde durmuştur. Bunlar (Karamustafa vd., 2002: 54-60); seyahat bilgileri, web sitesinde URL bulunması, elektronik posta, rezervasyon ile ilgili bilgiler, çevrimiçi rezervasyon oluşturabilme özelliği, çevimiçi ödeme yapılabilme özelliği, promosyonlar ve indirimler hakkında bilgiler, yabancı dil seçenekleri, geri bildirimde bulunabilme özelliği, işletme hakkında genel bilgiler, sıkça sorulan sorular özelliği, çalışanlara yönelik bilgiler, görsel içerikler olarak ifade edilmiştir.

Turizm sektöründe etkili web sitesi yaratmak, günümüzde birçok planlamadan önce gelmektedir. Bunu sağlayabilmek için bilgi kalitesini arttırmak, kullanım kolaylığı sağlamak, güvenlik ve kişisel bilgilerin korunmasına dikkat etmek, sorumluluk algısını oluşturmak ve belki de en önemlisi görsel içerikleri düzenlemek gerekmektedir (Dasgupta ve Utkarsh, 2014: 9-10). Günümüzde görsellik kavramı oldukça önemli seviyededir. Kullanıcıların görsel öğelere olan ilgisi, bir ürün ve hizmet satın alımında önemli rol oynamaktadır. Bu bağlamda görsel açıdan iyi planlanan web sitelerinin, başarı oranı daha fazla olabilmektedir.

Son birkaç yılda, çevrimiçi olarak yiyecek, içecek ve yemek satın alma konusunda tüketici istekleri, 2013'ten bu yana ortalama \%21,1 artışla geçen yıl artan harcamalarla birlikte büyük bir büyüme kaydetmiştir. 2017 yılı hem satışlar açısından hem de yiyecek ve içecek işletmelerinin eticaret tekliflerini tüketici taleplerinden yararlanmak için sağladığı gelişimler açısından sektör için büyük gelişimlerin yaşandığı bir yıl olmuştur (https://bit.ly/39UzkL7).

Pengnate ve Sarathy (2017) yaptıkları çalışmada bir websitesinin görsellerinin verimli ve çekici bir şekilde konumlandırılması, potansiyel kullanıcıların websiteleri ile ilgili önceden bilgisi olmadığ 1 durumlarda, kullanıcıların güven derecesi üzerinde doğrudan ve pozitif bir ilişki olduğunu doğrulamaktadır. Bu durumun en önemli getirisi ise artık websitelerin gelişigüzel kurulması yerine, daha planlı, yönetilebilirve doğru mesajı ulaştıran yapılarda kurulumunun sağlanmasıdır.

Turizm sektöründe çevrimiçi memnuniyet ile websitelerin kullanılabilirliği arasında oldukça önemli bir ilişki söz konusudur (Martinez-Sala vd., 2020: 2). Dijitalleşmenin önemi ile birlikte artan çevrimiçi ilgi, işletmelerin müşterilerini yönlendirmeleri açısından tasarımın önemini ortaya çıkarmıştır. Görsel öğelerin planlandığı ve kullanıcıların deneyimlerine göre iyileştirildiği dijital ortamlarda, kullanıcıların beklentilerini yönetmek büyük bir öneme sahiptir. Yapılan bir araştırma, mutlu bir dijital müşteri oluşturma aşamasında kullanıcıların beklentilerini şu şekilde ortaya koymaktadır (Yılmaz, 2000; akt. Fırlar ve Özdem, 2013: 6); hız, sadelik, kullanılabilirlik, içerik ve uyumluluk ve tasarımdır. Bir web sitesini başarıya ulaştıran önemli bir faktör olan tasarım, kullanıcıların deneyimlerini doğrudan yönlendirebilir.

İlgili alanyazın incelenmiş ve görsel içeriklerle ilgili madde listesi dört ana başlık ve 36 alt başlık üzerinden oluşturulmuştur (Clark vd., 1997; Abdullah, 1998; Karamustafa vd., 2002; Alican, 2014; Conte vd., 2005; Rudnicka, 2009; Bonnardel vd., 2011; Garrett, 2011; Yang, 2012; Drumeva, 2013; Frrlar ve Özdem, 2013; Boutique Media Communication, 2014; Jormakka, 2015; W3C, 2018, Kovacevic ve Brozovic, 2018; Khuong vd., 2018; Oyibo ve Vassileva, 2020); renkler, yapı (görsel hiyerarşi, mizanpaj ve denge), tipografi ve görsel objeler.

Bonnardel vd., (2011); renkler ve duygular arasında bir ilişkinin olduğunu ve bir renk seçiminin kullanıcıların duygularını ve geribildirimlerini etkileyebileceğini ortaya koymaktadır. Bir web sitesinde renk sadeliği iki ya da üç renk kullanımıyla çokça beyaz alan kullanımını ifade etmektedir (https://bit.ly/3qXNBh9). Dolayısıyla web sitelerinde renk sadeliğini sağlayabilmek için dörtten daha fazla renk kullanılmamalıdır. 
Tablo 1. İlgili Literatürde Yer Alan Görsel İçerik Maddeleri ve Alt Maddeleri

\begin{tabular}{|c|c|c|}
\hline Sira & $\begin{array}{c}\text { Görsel İçerik } \\
\text { Maddeler }\end{array}$ & Alt Maddeler \\
\hline \multirow{4}{*}{1.} & \multirow{4}{*}{ Renkler } & Sadelik (Beyaz alan kullanımı) \\
\hline & & Aynı renk, şekil ve dokuların kullanımı \\
\hline & & Sarı-beyaz, mavi-yeşil, kırmızı-siyah renk bileşimlerinin kullanılması \\
\hline & & Sıcak ve soğuk renklerin kullanılması \\
\hline \multirow{18}{*}{2.} & \multirow{18}{*}{$\begin{array}{c}\text { Yapı } \\
\text { (Görsel } \\
\text { hiyerarşi, } \\
\text { mizanpaj } \\
\text { ve denge) }\end{array}$} & Negatif alan kullanımı \\
\hline & & Yalın bir yapının olması \\
\hline & & Önem sırasının kullanılması \\
\hline & & İlişkili öğelerin kullanılması \\
\hline & & Kolay kullanım \\
\hline & & Sayfanın ana mesajı \\
\hline & & Yorumlanabilir ve anlaşılabilir olma \\
\hline & & Basit arayüz \\
\hline & & Mesaj (\#etiket) \\
\hline & & URL Özelliği \\
\hline & & Rezervasyon bilgisi \\
\hline & & Online rezervasyon \\
\hline & & Geri bildirim formu \\
\hline & & Promosyon bilgileri \\
\hline & & Online ödeme \\
\hline & & Sıkça sorulan sorular \\
\hline & & İçerik uyumu \\
\hline & & Espas \\
\hline \multirow{5}{*}{3.} & \multirow{5}{*}{ Tipografi } & İlgi çekici punto \\
\hline & & Dikkat çekici tipografik öğeler \\
\hline & & Başlik \\
\hline & & Hareket \\
\hline & & Metnin yerleşiminin yapılması \\
\hline \multirow{9}{*}{4.} & \multirow{9}{*}{ Görsel Objeler } & Resim \\
\hline & & Video \\
\hline & & Fotoğraflar \\
\hline & & Grafikler \\
\hline & & İllüstrasyonlar \\
\hline & & Fon Görseli \\
\hline & & Kadraj \\
\hline & & Çözünürlük \\
\hline & & İşlevsel Resimler \\
\hline
\end{tabular}

Kaynak: (Clark vd., 1997; Abdullah, 1998; Karamustafa vd., 2002; Alican, 2014; Conte vd., 2005; Rudnicka, 2009; Bonnardel vd., 2011; Garrett, 2011; Yang, 2012; Drumeva, 2013; Furlar ve Özdem, 2013; Boutique Media Communication, 2014; Jormakka, 2015; W3C, 2018, Kovacevic ve Brozovic, 2018; Khuong vd., 2018; Oyibo ve Vassileva, 2020).

Ivory ve Hearst'ın (2002) uzmanlar ve kullanıcılar üzerinde yaptıkları bir araştırmada 428 web sitesini incelemiş ve bir web sitesinde gövdenin vurgulanması ve metnin görüntülenmesi için renk kullanımının, metin bağlantıları için birden çok renk kullanımının ve metin bağlantıları 
yerine görüntü bağlantılarının kullanılmasının önemli olduğu çeşitli tasarım modellerini ortaya koymuşlardır. Web İçeriği Erişilebilirlik Yönergesi (W3C, 2018); kullanıcıların bir web sitesinde ön planı arka plandan ayırmak da dahil olmak üzere içeriği görmesini ve duymasını kolaylaştırmanın oldukça önemli olduğunu vurgulamaktadır. Dolayısıyla kullanıcılara iyi bir deneyim sunmanın en önemli yollarından birinin onlara uygun bir web içeriği tasarlamak olduğu sonucuna ulaşmışlardır.

Web tasarımları dahil olmak üzere tüm görsel içerikler için önemli bir özellik olan tipografi, harf ve sembollerin kullanılmasıyla ortaya çıarılan yazı sanatı olarak ifade edilmektedir (Drumeva, 2013). Web sitelerinde doğru bir altyapı ile belirlenmeyen görsel metin içerikleri, kullanıldıkları içeriklere (başlık, ana sayfanın mesajı, alt metin bölgeleri) göre iyi bir şekilde planlanmayan yazı karakterleri, okunurluk ve kullanıcı deneyimi açısından büyük sorunlar oluşmasına neden olmaktadır (Alican, 2014: 86). Drumeva'ya (2013) göre tipografi; bir web site tasarımında okuyucuyu gereksiz süsleri maruz bırakmadan en önemli bilgileri sunmalı ve akıldaki en önemli sorulara yanıt verebilmelidir. İtalik ve kalın harflerin kullanımı web siteyi grafik olarak zenginleştirmektedir. Bu şekilde, büyük metin bloklarının sıkıcılığı ve monotonluğu aşılır ve kompozisyona sanatsal bir ritim eklenmiş olabilmektedir. Bu durum ise kullanıcının dikkatini çeker ve görsel stresi azaltır.

Web sitelerdeki görsel objelere tüketici davranışları açısından bakıldığında, algılama sürecinde duyulara ulaşmak en önemli aşamayı oluşturabilir. Bir web sitedeki içerikler, bunların dizaynı ve konumlandırılması, marka isimleri, ambalaj renkleri ya da planlanan promosyonların her birinin bir uyarı rolünde görev yaptıkları bilinmektedir. Sonrasında ise beyin ön plana çıkmakta ve beynin içerisinde oluşan dışsal etkilere karşı olumlu veya olumsuz tepkiler ortaya çıkmaktadır. Tüketiciler hayatları boyunca çok fazla uyarıcı ile karşılaşmakta, ancak bu uyarıcıların yalnızca bir bölümünü algılayabilmektedirler. Bu süreçte bazen kişi uyarıcılar üzerinde algılanması istenilen ile algılanan uyarıcılar arasında fark oluşturabilmektedir. Bu algılama sürecinde bireyin sahip olduğu dışsal etkinin bilincinde olması ve onu doğru olarak algılaması pazarlamada satın alma süreci açısından oldukça önemlidir. Algılama süreci, kişinin dışsal etkiyle kaldığı süreçte başlamakta ve bir tepkime olarak öğrenme sonunda gerçekleşen satın alma eylemi ile son bulmaktadır (Koç, 2011: 22; Kesek, 2017: 21).

Web sitelerinde kullanılan görsel objelerin kullanımına ilişkin bazı ölçütler bulunmaktadır. Bunlardan birincisi ve önemlilerinden biri; sayfanın arka planı ile ilgilidir. Arka planda resim kullanımı estetik bir yapı sağlanarak verilmelidir. İkincisi ise görsel objelerde kullanıcılara sunulan mesajlardır. Burada en çok dikkat edilmesi gereken konuların başında ise mesajların her bir obje üstünde tek olmasıdır. Çoklu mesajlar görsel karmaşıklığa sebep olabilmektedir. Dolayısıyla kullanılan mesaj sade, anlaşılabilir ve tek, aynı zamanda metinle ilgiliyi de yüksek olmalıdır. Bir web sitesinde görsel objelerin kadrajlaması da önemli bir ölçüttür. Çerçeveleme anlamına gelen kadrajlama, sayfanın kullanıcılara vermek istediği ana mesaja göre konumlandırılmalıdır (Fırlar ve Özdem, 2013). Bu ölçütler dahilinde oluşturulan web siteleri görsel objeleri, etkili pazarlama içerikleri oluşturmada katkı sağlayabilir.

Web sitelerinde renkler ve duygular arasında bir ilişki vardır ve bir renk seçiminin kullanıcıların duygularını ve geribildirimlerini etkileyebilmesi mümkündür (Bonnardel vd., 2011: 71). Web sitelerde renklerin böylesine önemli bir etkiyi yaratabilmesi için belirli bir renk uyumunun sağlanması gerekmektedir. Yapılacak olan renk planlamaları ile web sitelerin görsel içerik performansı arttırılabilir.

Coleman (2010) görsel içeriklerde kadraj kullanımının görsel etkileri keşfetme açısından önemli olduğunu, insanların kafalarında eksik kalan çerçeveleri şekillendirdiğini ve bunun da görsel 
açıdan etkisi olduğunu belirtmektedir. Dolayısıyla işlevsel bir yemek fotoğrafının kadraj özelliği kullanılarak verilmesi, müşterilerin kullanıcı deneyimini yükseltebilir.

$\mathrm{Bu}$ bağlamda ilgili literatür ile bir web sitesinde olması gereken görsel içerik maddeleri sıralanarak dört adet ana madde ve 36 adet alt maddenin belirlenmesi sağlanmıştır. Bu ana ve alt maddeler ise dünyanın en çok tercih edilen dört yiyecek işletmesinin web siteleri üzerinden içerik analizi yapılarak incelenmiştir.

\section{YÖNTEM}

Araştırmada dünyanın en çok tercih edilen dört yiyecek işletmesinin web sitesi içerik analizi yöntemiyle incelenmiştir. Web sitelerdeki ortalama kalış süreleri, web sayfalarının ortalama görüntülenme sayısı, web sitelerdeki toplam kelime sayıları ve hiper-metin özellikleri tespit edilmiş; görsel içerikler ise literatürden çıkarılan dört ana madde ve alt maddeleri olan 36 madde ile araştırmanın temaları olarak kabul edilmiş ve bu temalara göre bir kontrol listesi oluşturularak kodlamaları yapılmıştır. Dolayısıyla bu çalışmada bireyler üzerinde herhangi bir uygulama yapılmadığı için etik kurul raporuna ihtiyaç duyulmamıştır.

www.similarweb.com web sitesinde yer alan verilere göre dünyada yiyecek içecek sektörüyle ilgili en çok tercih edilen ilk 50 web site sıralanmıştır. Bu listedeki kategori sıralamasının; yemek tarifleri paylaşan web siteleri, yiyecek satışı yapan web siteleri, restoran ve yiyecek teslimi sağlayan web siteleri olmak üzere üç aşamada sıralandığı görülmektedir. Bu kategori sıralaması içinde restoran ve yiyecek teslimi sağlayan işletmeler çalışma alanı olarak seçilmiş ve bu listede kategori sınırlandırılması yapılmış 50 web siteden dördünün bu kategoriye girdiği görülmüştür. Dolayısıyla araştırmada içerik analizi yapılan web sitesi sayısı dörde indirilmiştir. Çalışmada etik açıdan restoranların isimleri ve logolarına yer verilmemiştir.

\section{BULGULAR}

Çalışmada dört web sitesinin içerik analizi yapılırken, her bir web sitesinde yer alan toplam kelime sayıları ve hiper-metin özellikleri de incelenmiştir. Bir insanın bir dakika içinde algılayabileceği kelime kapasitesi 600, saniyede algılayabileceği kelime sayısı ise 10'dur. Normal bir insanın düşünce hızı dakikada 750-800 kelime, saniyede ise yaklaşık olarak 12,5-13 kelime arasındadır (Ekmekçi, 2019: 32). Nörobilim çalışmalarında dikkat düzeyinin ise ilk 20 dakika olduğu bilinmektedir.

Tablo 2. Araştırmada İçerik Analizi Yapılan Restoranların Bilgileri (1 Haziran Verilerine Göre)

\begin{tabular}{ccccccc} 
Sıra & $\begin{array}{c}\text { Restoran } \\
\text { Kodu }\end{array}$ & $\begin{array}{c}\text { Restoran } \\
\text { Türü }\end{array}$ & $\begin{array}{c}\text { Ortalama } \\
\text { Karetçi } \\
\text { Käış } \\
\text { Süri } \\
\text { (dk) }\end{array}$ & $\begin{array}{c}\text { Website } \\
\text { Sayfalarının } \\
\text { Ortalama } \\
\text { Görüntülenme } \\
\text { Sayısı }\end{array}$ & $\begin{array}{c}\text { Websitelerindeki } \\
\text { Toplam } \\
\text { Kelime Sayısı }\end{array}$ & $\begin{array}{c}\text { Hiper- } \\
\text { Metin }\end{array}$ \\
\hline $\mathbf{1}$ & $\mathbf{R} \mathbf{1}$ & Teslim & $07: 43$ & 5,68 & 5257 & HTML \\
\hline $\mathbf{2}$ & $\mathbf{R} \mathbf{2}$ & Teslim & $08: 46$ & 8,23 & 4762 & HTML \\
\hline $\mathbf{4}$ & $\mathbf{R 3}$ & $\begin{array}{c}\text { Satı̧ ve } \\
\text { Teslim }\end{array}$ & $07: 46$ & 5,69 & 4930 & HTML \\
\hline $\mathbf{5}$ & $\mathbf{R} \mathbf{4}$ & $\begin{array}{c}\text { Satış ve } \\
\text { Teslim }\end{array}$ & $06: 41$ & 7,99 & 4691 & HTML
\end{tabular}

Kaynak: (https://bit.ly/3sNr9c1). 
Tablo 3. İçerik Analizine Göre Tema ve Kodların Oluşturulması

\begin{tabular}{|c|c|c|c|c|c|c|c|c|c|c|c|}
\hline \multirow{2}{*}{ 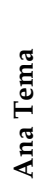 } & \multirow[b]{2}{*}{ Alt Tema } & \multicolumn{4}{|c|}{ Restoran Kodları } & \multirow{2}{*}{ 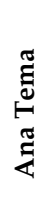 } & \multirow[b]{2}{*}{ Temalar } & \multicolumn{4}{|c|}{ Restoran Kodları } \\
\hline & & R1 & $\mathbf{R} 2$ & R3 & R4 & & & R1 & $\mathbf{R} 2$ & R3 & R4 \\
\hline \multirow{5}{*}{$\frac{\grave{c}}{\frac{ \pm}{z}}$} & $\begin{array}{l}\text { Sadelik (Beyaz } \\
\text { alan kullanımı) }\end{array}$ & + & + & + & + & & $\begin{array}{c}\text { Sikça sorulan } \\
\text { sorular }\end{array}$ & + & + & + & + \\
\hline & $\begin{array}{c}\text { Aynı renk, şekil ve } \\
\text { dokuların } \\
\text { kullanımı }\end{array}$ & + & + & + & + & & İçerik uyumu & + & + & + & + \\
\hline & $\begin{array}{l}\text { Sarı-beyaz, mavi- } \\
\text { yeşil, kırmızı-siyah } \\
\text { renk bileşimlerinin } \\
\text { kullanılması }\end{array}$ & + & + & + & + & & Espas & & + & + & + \\
\hline & Sicak ve soğuk & & & & & \multirow{5}{*}{ 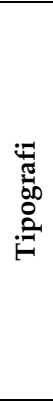 } & İlgi çekici punto & + & + & + & + \\
\hline & $\begin{array}{c}\text { renklerin } \\
\text { kullanılması }\end{array}$ & + & + & + & + & & $\begin{array}{c}\text { Dikkat çekici } \\
\text { tipografik öğeler }\end{array}$ & + & + & + & + \\
\hline \multirow{17}{*}{ 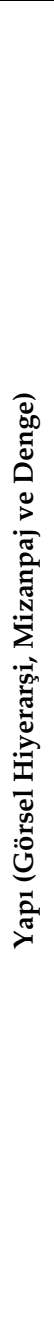 } & $\begin{array}{c}\text { Negatif alan } \\
\text { kullanımı }\end{array}$ & & & + & + & & Başlık & + & + & + & + \\
\hline & $\begin{array}{c}\text { Yalın bir yapının } \\
\text { olması }\end{array}$ & + & + & + & + & & Hareket & + & + & + & + \\
\hline & $\begin{array}{l}\text { Önem sırasının } \\
\text { kullanılması }\end{array}$ & & & & + & & $\begin{array}{c}\text { Metnin } \\
\text { yerleşiminin } \\
\text { yapılması } \\
\end{array}$ & + & + & + & + \\
\hline & \multirow[b]{2}{*}{$\begin{array}{c}\text { İlişkili öğelerin } \\
\text { kullanılması }\end{array}$} & \multirow[b]{2}{*}{+} & \multirow[b]{2}{*}{+} & \multirow[b]{2}{*}{+} & \multirow[b]{2}{*}{+} & \multirow{11}{*}{$\begin{array}{l}\frac{\vdots}{0} \\
\frac{0}{0} \\
0 \\
0 \\
0 \\
0 \\
000 \\
0 \\
0\end{array}$} & Resim & + & + & + & + \\
\hline & & & & & & & Video & + & + & + & + \\
\hline & Kolay kullanım & & + & + & + & & Fotoğraflar & + & + & + & + \\
\hline & $\begin{array}{c}\text { Sayfanin ana } \\
\text { mesajı }\end{array}$ & + & + & + & + & & Grafikler & + & & + & + \\
\hline & \multirow{2}{*}{$\begin{array}{l}\text { Yorumlanabilir ve } \\
\text { anlaşılabilir olma }\end{array}$} & \multirow[b]{2}{*}{+} & \multirow[b]{2}{*}{+} & \multirow[b]{2}{*}{+} & \multirow[b]{2}{*}{+} & & İllüstrasyonlar & + & + & + & + \\
\hline & & & & & & & Fon Görseli & + & + & + & + \\
\hline & Basit arayüz & & + & + & + & & Kadraj & & & + & \\
\hline & Mesaj (\#etiket) & & & & & & Çözünürlük & + & + & + & + \\
\hline & URL Özelliği & + & + & + & + & & İşlevsel Resimler & + & + & + & + \\
\hline & $\begin{array}{c}\text { Rezervasyon } \\
\text { bilgisi } \\
\end{array}$ & + & + & + & + & & & & & & \\
\hline & $\begin{array}{c}\text { Online } \\
\text { rezervasyon }\end{array}$ & + & + & + & + & & & & & & \\
\hline & $\begin{array}{l}\text { Geri bildirim } \\
\text { formu }\end{array}$ & + & + & + & + & & & & & & \\
\hline & $\begin{array}{c}\text { Promosyon } \\
\text { bilgileri }\end{array}$ & + & + & + & + & & & & & & \\
\hline & Online ödeme & + & + & + & + & & & & & & \\
\hline
\end{tabular}


Tablo 2'de yer alan verilerde; ortalama ziyaretçi kalış süresi, web sayfalarının ortalama görüntülenme sayısı ve web sitelerindeki toplam kelime sayıları yer almaktadır.

Dolayısıyla araştırmaya konu olan web sitelerindeki bir ziyaretçinin ortalama kalış süresi ile o web sitesinde yer alan kelime sayıları Tablo 2' deki bilgilere göre karşılaştırılmıştır;

- R1'deki ortalama ziyaretçi kalış süresinin 7 dk. 43 sn. (463 sn.) olduğu görülmektedir. R1'de yer alan toplam kelime sayısı ise 5257'dir. Dolayısıyla R1'de saniye başına 11,4 kelime düşmektedir.

- R2'de ortalama ziyaretçi kalış süresinin 8 dk. 46 sn. (526 sn.) olduğu görülmektedir. R2' de yer alan toplam kelime sayısı ise 4762 'dir. Dolayısıyla R2'de saniye başına 9,1 kelime düşmektedir.

- R3'de ortalama ziyaretçi kalış süresinin $7 \mathrm{dk}$. $46 \mathrm{sn}$. (466 sn.) olduğu görülmektedir. R3'de yer alan toplam kelime sayısı ise 4930'dur. Dolayısıyla R3'de saniye başına 10,6 kelime düşmektedir.

- R4'de ortalama ziyaretçi kalış süresinin 6 dk. 41 sn. (401 sn.) olduğu görülmektedir. R4'de yer alan toplam kelime sayısı ise 4691 'dir. Dolayısıyla R4'de saniye başına 11,7 kelime düşmektedir.

Yapılan içerik analizi sonucuna göre R1, R2, R3 ve R4 web sitelerinde beyaz alanların kullanım çokluğunun olduğu (Resim-1) ve aynı renk şekil ve dokuların kullanımı alt maddesine göre bu özellikleri de karşıladıkları görülmüştür. Sadeliği oluşturan özelliklere önem verilen bu web sitelerinde, müşterilerin sıklıkla bu web sitelerini tercih etmesi ile web sitelerinde bu yapıları oluşturmanin etkili olduğu görülmektedir.

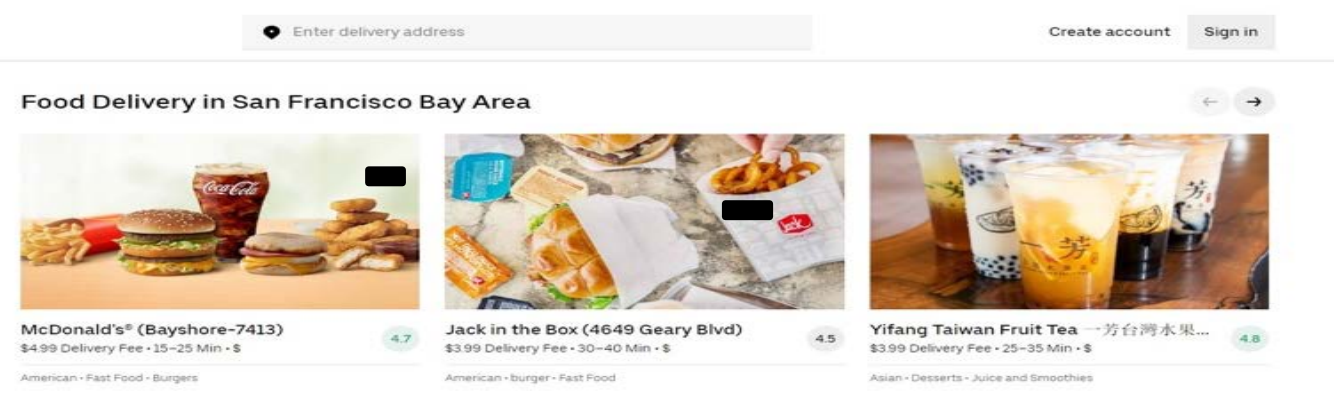

Resim 1. R2 Beyaz Alan Kullanımı

R1, R2, R3 ve R4 web sitelerinde sarı-beyaz, mavi yeşil, kırmızı-siyah renk bileşimlerinin ve sıcaksoğuk renklerin bir arada kullanıldığı tespit edilmiştir. Bu renkler üzerinden oluşturulan yapılar, müşterilerin ilgisini çekebilmektedir. Dolayısıyla müşterilerin satın alma davranışını etkileyebilen bu özellikleri sağlamak, kullanıcı deneyimi açısından önemli olabilir. Dört web sitenin de bu özelliği sağlaması, dünyanın en çok tercih edilen web siteleri olan bu dört web sitenin doğru bir içerik planlaması yaptığını ortaya çıkarmaktadır.

Yapı (Görsel Hiyerarşi, Mizanpaj ve Denge) maddesine göre R1, R2, R3 ve R4 web sitelerinde yalın yapı, ilişkili öğe kullanımı, ana mesajın varlığı, yorumlanabilir ve anlaşılabilir içerik, URL özelliği, rezervasyon bilgisi, online rezervasyon sekmesi, geri bildirim formu, online ödeme, sıkça sorulan sorular sekmesi, içeriklerin birbirleriyle uyumunun olduğu görülmektedir. Dolayısıyla bu maddelerin web sitelerindeki etkisi önemlidir. 

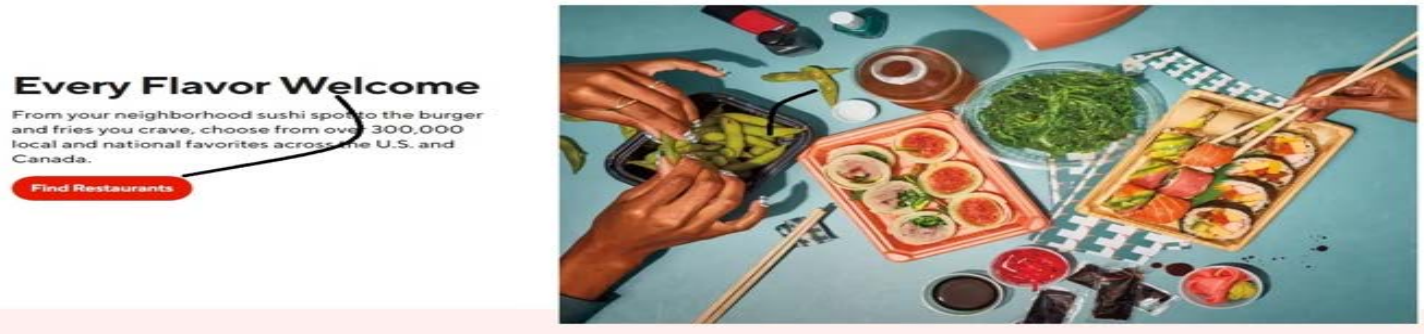

Resim 2. R1 Kırmızı-Siyah, Mavi-Yeşil Renk Kullanımı

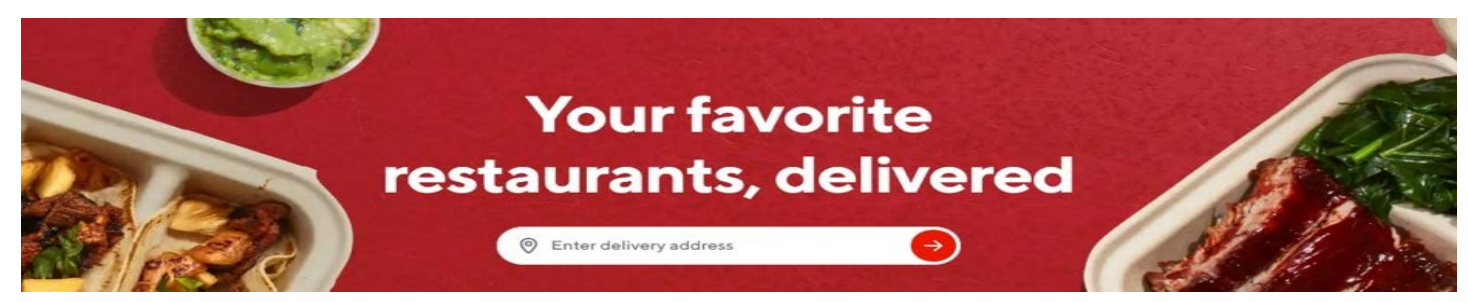

Resim 3. R1 Sayfanın Ana Mesajı

Araştırmaya konu olan ve içerik analizi yapılan restoranların hiçbirinde etiket kullanılmadığı tespit edilmiştir. Bunun temel sebebi olarak etiket kullanımının sosyal medya araçlarında daha çok kullanılması olabilir. Fakat web sitelerinin geleceği düşüldüğünde, etiketleri temsil eden anahtar kelimeler, o web sitelerinde kullanılacak olan bir kampanya ya da mesaj açısından önemli bir kanalı oluşturabilir.

R1, R2, R3 ve R4 web sitelerindeki puntoların ilgi çekici olduğu görülmektedir. Her bir restoranın hem sayfanın ana mesajında hem de diğer sekmelerinde müşterinin ilgisini çekebilecek puntolar kullandığ 1 tespit edilmiştir. Bu durum, web sitelerinde punto kullanımının verimli olduğunu göstermektedir. Web sitelerinde ilgi çekici puntolar kullanmak, sadeliği korumak ve müşterilerin kullanıcı deneyimlerini arttırmak için önemlidir. Dolayısıyla doğru punto kullanımını dört web sitenin de sağladığı görülmektedir.

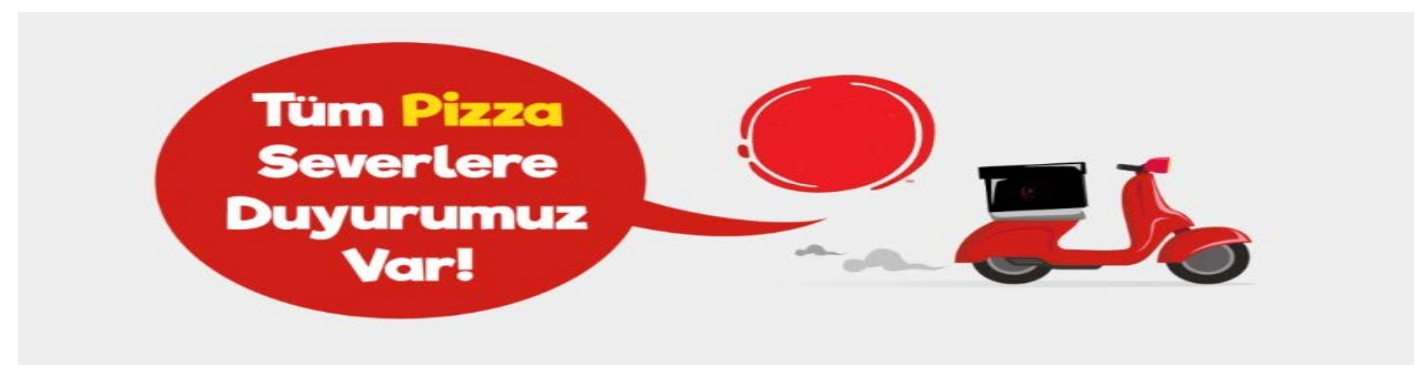

Resim 4. R4 Punto Kullanımı

İncelenen 4 restoranın görsel objeler açısından resim, video, fotoğraf ve illüstrasyon kullandıkları tespit edilmiştir. Görsel objelerin doğru kullanımı, müşterilerin web sitelerden aldıkları deneyimleri arttırabilir. Kullanıcı deneyimi ile doğru orantılı bir şekilde web sitenin 
performansını yükselten en önemli aşmalardan biri olan görsel obje kullanımı ve konumlandırılması, müşterilere ürün ve hizmetlerle ilgili ilgi çekici bir yönlendirme sağlayabilir.

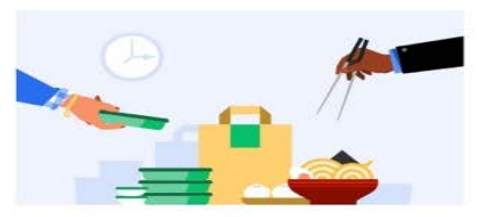

Feed your employees Create a business account

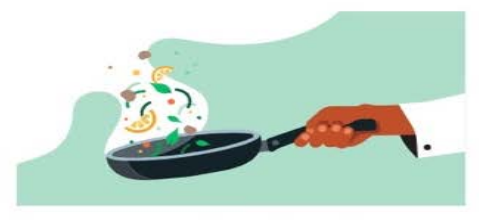

Your restaurant, delivered Add your restaurant

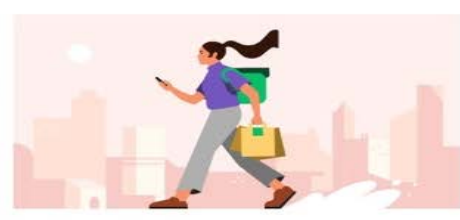

Deliver the Eats Sign up to deliver

Resim 5. R2 İllüstrasyon Kullanımı

Yön, hareket ve çözünürlük açısından R1, R2, R3 ve R4'ün ilgili alt maddelere uyduklar1 görülmektedir. Kadraj kullanımını yalnızca R3'ün uyguladığı, aynı zamanda incelenen tüm restoran web sitelerinde işlevsel resimlerin kullanıldığı tespit edilmiştir. İncelenen dört web sitesinde kadraja olan ilgi ise her ne kadar tespit edilemese de kadrajın sağlayacağ merak hissi, müşterilerin tercihlerinde etkili olabilir. Çünkü işlevsel fon görsellerinde kullanılan kadraj özelliği, müşterileri yönlendirme ve merak uyandırma açısından önemli bir görsel kullanım alanı yaratabilir.

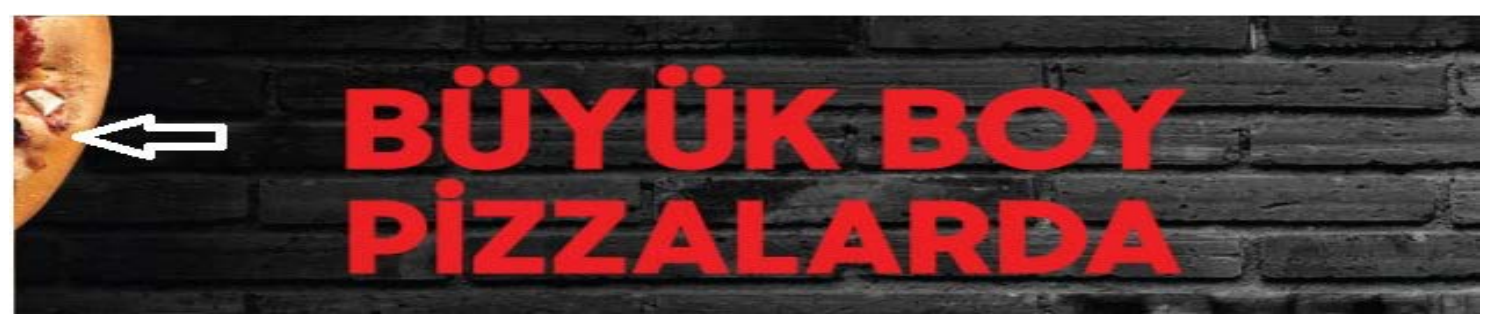

Resim 6. R4 Kadraj Kullanımı

Resim-6'da R4'ün web sitesinde yer alan bir sekmede büyük ana başlık, altında yer alan bir görsele yerleştirilmiştir. Fakat bu görselin sol kısmında görünen pizzanın kadraja çok az girdiği görülmektedir. Bu da merak hissi uyandırmada etkisiz kalabilir.

\section{SONUÇ ve ÖNERILER}

Dünyanın en çok tercih edilen dört yiyecek işletmesinin web sitesi içerik analizi yöntemiyle incelenmiştir. $\mathrm{Bu}$ web sitelerindeki ortalama kalış süreleri, web sayfalarının ortalama görüntülenme sayısı, web sitelerindeki toplam kelime sayıları ve hiper-metin özellikleri tespit edilmiş; görsel içerikler ise literatürden çıkarılan 4 ana madde ve alt maddeleri olan 36 madde ile araştırmanın temaları olarak kabul edilmiş ve bu temalara göre bir kontrol listesi oluşturularak kodlamaları yapılmıştır.

İçerik analizi sonuçlarına göre incelenen dört restoran web sitesinin de birbirleriyle benzer özelliklere sahip olduğu sonucuna varılmıştır. Bu web sitelerinin renkler ana maddesinde yer alan sadelik (beyaz alan kullanımı özelliğini taşıdığı görülmektedir. Sik Lanyi (2012) web 
sitelerinde kullanılan efektif renkleri ortaya çıkarmak amacıyla yaptığı bir araştırmada, web sitelerinde kullanılan beyaz alanların saflığı temsil ettiğini belirtmiştir.

Araştırmanın diğer sonuçlarına bakıldığında aynı renk, şekil ve dokuların kullanımı, sarı-beyaz, mavi-yeşil, kırmızı-siyah renk bileşimlerinin kullanılması ve sıcak ve soğuk renklerin kullanılması alt maddelerinin hepsini karşıladıkları ortaya çıkarılmıştır. Bonnardel vd., (2011) renkler ve duygular arasında bir ilişkinin olduğunu ve bir renk seçiminin kullanıcıların duygularını ve geribildirimlerini etkileyebileceğini ortaya koymaktadır. Dolayısıyla müşteriler tarafından dünyanın en çok tercih edilen yiyecek işletmelerinin web siteleri olan dört web sitenin de renk konusunda görsel bir altyapısının olduğu ve ilgili literatürde de belirlenen, müşteriler tarafından verimli algılanabilecek renkleri kullandıkları sonucu ortaya çıkarılmıştır.

R1 ve R2'nin görsel içeriklerde önemli bir yeri olan negatif alanı kullanmadığı sonucuna varılmıştır. Analiz edilen dört web sitesinin de yalın bir yapıya sahip olduğu görülmektedir.

Coleman (2010) görsel içeriklerde kadraj kullanımının görsel etkileri keşfetme açısından önemli olduğunu, insanların kafalarında eksik kalan çerçeveleri şekillendirdiğini ve bunun da görsel açıdan etkisini ortaya çıkarmıştır. Sayfalarında ana mesaja yer veren dört web sitesinin günümüz dijital pazarlama araçlarından bir olan etiket (\#) kullanmamaları ise olumsuz bir sonuç olarak karşımıza çıkmaktadır.

(Ekmekçi, 2019: 32) normal bir insanın düşünce hızının dakikada 750-800 kelime, saniyede ise yaklaşık olarak 12,5-13 kelime arasında olduğunu belirtmektedir. R1'de saniye başına 11,4 kelime düşmektedir. Normal bir insanın düşünce hızının dakikada 750-800 kelime, saniyede ise yaklaşık olarak 12,5-13 kelime arasında olduğu düşünüldüğünde; R1'in kelime sayısı açısından normal bir insanın düşünce hızına uygun olduğu sonucuna varılmıştır. Dolayısıyla R1'de yer alan içeriğin planlamasının doğru yapıldığı görülmektedir.

R2' de ise saniye başına 9,1 kelime düştüğü ortaya çıkarılmıştır ve bu durum R2'nin kalış süreleri ortalamaları açısından web sitesindeki toplam kelime sayısının düşük olduğu sonucuna varılmıştır. Çünkü R2'de ortalama ziyaretçi kalış süresi 8 dk. 46 sn. (526 sn.) olduğu görülmektedir. Bunun anlamı ziyaretçilere daha fazla içeriğin sunulabilir olduğudur.

R3'de saniye başına 10,6 kelime düşmektedir ve içerik açısından kısmen geliştirilebilir olduğu görülmektedir. R4'de ise saniye başına 11,7 kelime düşmektedir ve ilgili rakama (12,5-13 sn.) kısmen yakın olduğu sonucuna ulaşılmıştır.

URL özelliği, online rezervasyon imkanı ve online ödeme gibi özellikle 2020 ve 2021 yıllarındaki pandemi günlerinde önemli bir yer tutan bu özellikleri kullanmaları, incelenen web siteleri için önemlidir. Fakat bunun önemli sebeplerinden biri de incelenen bu dört web sitesinin ikisinin teslim, diğer ikisinin ise satış ve teslim özellikli markalar olmasıdır. Dolayısıyla teslimat odaklı çalışan markaların online rezervasyon ve online ödeme gibi imkanları web sitelerinde sağlamak zorunda oldukları da açıktır.

Drumeva'ya (2013) göre tipografi; bir web sitesi tasarımında okuyucuyu gereksiz süsleri maruz bırakmadan en önemli bilgileri sunmalı ve akıldaki en önemli sorulara yanıt verebilmelidir. Bu kullanıcının dikkatini çeker ve görsel stresi azaltır. İlgi çekici puntolar kullandıkları görülen R1, R2, R3 ve R4'ün web sitelerinde müşterilerine resim, fotoğraf, video içerikleri sağladıkları görülmektedir. Bu durum web sitelerindeki görsel içerik bazlı kullanıcı deneyim performansını arttırmaktadır.

Bu sonuçlar doğrultusunda çalışmanın önerileri ise şu şekildedir;

- Görsel içerik planlamasında önemli bir yeri olan negatif alan kullanımına daha fazla özen gösterilmelidir, 
- Web sitelerinde önem sıralaması yapılabilir,

- Dijital dünyanın pazarlama araçlarından biri olan internette yeni anahtar kelimeleri belirlemek etiketleri oluşturmayla sağlanabilir. Dolayısıyla web sitelerinin kendi markaları için etiket kullanmaları özellikle günümüz dijital pazarlama dünyasında kaçınılmazdır,

- Günümüzde bilgisayarların çalışma sistemi düşünüldügünde web sitelerinde kullanılacak grafikler için daha fazla çalışmalar yapılabilir,

- Bir yiyecek içecek işletmesi web sitesinde yemeklerin yer aldığı görsellerde kadraja dikkat edilmelidir,

- Nörobilim çalışmaları ile bir web sitesinde olması gereken görsel içerik özellikleri detaylı bir şekilde incelenebilir,

- Yiyecek içecek işletmesi web sitelerindeki hiper-metin özelliklerine yönelik olarak nöropazarlama odaklı çalışmalar yapılabilir,

- Bir yiyecek içecek işletmesi web sitesinde yer alan toplam kelime sayısı ile müşterilerin kalış süreleri hakkında daha detaylı çalışmalar yapılabilir,

- İncelenecek daha farklı web siteleriyle bu tarz çalışmalar geliştirilebilir ve ideal bir yiyecek içecek işletmesi web sitesinde kullanılması gereken görsel içerikler ortaya çıkarılabilir.

\section{KAYNAKÇA}

Abdullah, M.H. (1998). Guidelines for Evaluating Web Sites. ERIC Digest, This Digest Was Created By ERIC, The Educational Resources Information Center, ERIC Clearinghouse on Reading English and Communication Bloomington IN. (ERIC Document Reproduction Service No. ED426440).

Alican, Ö. (2014). Esnek Web (Responsive Web) Sitesi Tasarımında Tipografi Sorunları. Yedi: Sanat, Tasartm ve Bilim Dergisi, 12, 85-91.

Azaltun, M. (2000). Turistik Ürün Çeşitlerinin Pazarlanmasında Web Sitelerinin Kullanımı Üzerine Bir Araştırma. I. Ulusal Türkiye Turizmi Sempozyumu, Türkiye Turizmini Araştırma Enstitüsü, 2-3 Kasım 2000, ss. 23- 43.

Bilgilier, H.A.S. (2016). İletişim Penceresinden Coca Cola Türkiye, Turkcell ve Türk Hava Yolları'nın Resmi Web Siteleri Üzerine Bir Analiz. Uluslararası Sosyal Araştırmalar Dergisi, 9(45), 714-721.

Bonnardel, N., Piolat, A. and Ludovic, L.B. (2011). The Impact of Colour on Website Appeal and Users' Cognitive Processes. Displays, 32, 69-80.

Coleman, R. (2010). Framing the pictures in our heads: Exploring the framing and agenda-setting effects of visual images. Routledge Taylor \& Francis Group New York and London, Chapter 10, 233-262.

Conte T., Mendes and E., Travassos, G., H., (2005). Development Processes for Web Applications: A Systematic Review. Proceedings of XI Simpósio Brasileiro de Multimídia e Web - WebMedia, Poços de Caldas, Brasil, 2005.

Dasgupta, D. and Utkarsh. (2014). Assessing the website effectiveness of top ten tourist attracting nations. Information Technology \& Tourism, Inf Technol Tourism, 14(2), 151-175. 
Drumeva, K. (2013). Basic aspects of typography in designing a web page, Art, Design and Art Education: Methods and Experiences of Creativity Development at Kaunas University of Applied Sciences Justinas Vienožinskis Faculty of Art, November, 2013.

Furlar, B ve Okat Özdem, Ö. (2013). Web Tasarımının Önemi: Destinasyon Web Sitelerinin Görsel Tasarımlarının Değerlendirilmesi. ODÜ Sosyal Bilimler Araştırmaları Dergisi, 4 (7), 5-16.

Ekmekçi, R. (2019). Sporda Zihinsel Antrenman (Bir Adım Önde) Psikolojik Performans-Beyin Nasıl Çalışır?-Stres Yönetimi-Motivasyon-Beyin ve Beslenme-Spor Genetiği. Detay Yayıncılık, İkinci Baskı, Ankara, 2019.

Garrett, J.J. (2011). The Elements of User Experience: User-Centered Design for the Web and Beyond. New Riders Voice That Matter, The 2nd Edition, Berkeley, CA.

http://fearlessflyer.com/the-importance-of-simplicity-in-web-design/, Son Erişim Tarihi: 19.06.2020.

https://www.similarweb.com/top-websites/category/food-and-drink, Son Erişim Tarihi: 01.06 .2020

https://www.yieldify.com/wp-content/uploads/2018/04/food-drink-e-commerce.pdf, (Son Erişim Tarihi: 13.11.2019.

Ivory, M.Y. and Hearst, M.A. (2002). Statistical Profiles of Highly-Rated Web Sites. Proceedings of the Conference on Human Factors in Computing Systems, April 2002.

Jormakka, E.S.F. (2015). Visualizing the User Experience on Website. Bachelor's Thesis, Karelia Ammattikorkeakoulu Karelia University of Applied Sciences Degree Program in Design, p.45., Spring, 2015.

Karamustafa, K., Biçkes, D.M. ve Ulama, Ş. (2002). Türkiye'deki Konaklama İşletmelerinin İnternet Web Sitelerini Değerlendirmeye Yönelik Bir Çalışma. Erciyes Üniversitesi İktisadi ve İdari Bilimler Fakültesi Dergisi, 19, 51-92.

Kesek, H. (2017). Nöropazarlama Yaklaşımının Tüketici Davranışları Üzerindeki Etkisi: Malatya İnönü Üniversitesi Örneği. Yüksek Lisans Tezi, KTO Karatay Üniversitesi Sosyal Bilimler Enstitüsü İşletme Anabilim Dalı Yüksek Lisans Programı, Konya.

Khuong, T.T., Dinh Thanh Nhan, P.Y.N. and Thuan, N.H. (2018). Colour, Trust, Satisfaction, and E-loyalty: The Vietnamese Experience of Website Design. ICMLSC'18, February 2-4, 2018, Phu Quoc Island, Vietnam, ACM. ISBN: 978-1-4503-6336-5. DOI: http://dx.doi.org/10.1145/12345.67890.

Koç, E. (2011). Tüketici Davranışı ve Pazarlama Stratejileri Global ve Yerel Yaklaşım. Seçkin Yayıncilık, Ankara.

Kovacevic, D. and Brozovic, M. (2018). Differences Between Designers' and Users' Perception of Instructions Design. 8th Conference on Information and Graphic Arts Technology, 7-8th June, University of Zagreb.

Martínez-Sala, A.-M., Monserrat-Gauchi, J., and Alemany-Martínez, D. (2020). User Usable Experience: A three-dimensional approach on usability in tourism websites and a model for its evaluation. Tourism Management Perspectives, 33, 1-13.

Murphy, J., E.J. Forrest., C.E. Wotring and R.A. Brymer. (1996), Hotel Management and Marketing on The Internet, Cornell Hotel and Restaurant Administration Quarterly. 37(3): 70-82. 
Oyibo K and Vassileva J. (2020). The Effect of Layout and Color Temperature on the Perception of Tourism Websites for Mobile Devices. Multimodal Technologies and Interaction, 4(1): 1-13.

Palmer, A. and P. McCole. (2000), The Role Electronic Commerce in Creating Virtual Tourism Destination Marketing Organisations. Internet Journal of Contemporary Hospitality Management, 12(3): 198-204.

Pengnate, S. (Fone) and Sarathy, R. (2017). An experimental investigation of the influence of website emotional design features on trust in unfamiliar online vendors. Computers in Human Behavior, 67, 49-60.

Rudnicka, P. (2009). User Experience (UX) of Corporate Websites: Usability, Marketing, Strategies and Emotional Response. In: L. Karamushka, and B. Kożusznik (Eds.). Work and Organizational Psychology Problems and Challenges in Poland and Ukraine. (pp. 42-43). Book of Abstracts. Kyiv: Kvitka.

Sana Commerce (2017). Trend report: The Digital Future of the Food and Beverage Industry. Food $\mathcal{E}$ Beverage Industry Trend Report, 3-11.

Sik-Lanyi, C. (2012). Choosing effective colors for web sites, (Editör) Best, J. Colour Design Theories and Applications içinde (ss.600-621). Woodhead Publishing Limited.

Tierney, P. (2000), Internet-Based Evaluation of Tourism Web Site Effectiveness: Methodological Issues and Survey Result. Journal of Travel Research, 39, 212-219.

Weichbroth, P., Redlarski, K. and Garnik, I. (2016). Eye-tracking Web Usability Research. The Federated Conference on Computer Science and Information Systems, ACSIS, 8, 1681-1684.

Yang, S.S. (2012). Eye movements on restaurant menus: A revisitation on gaze motion and consumer scanpaths. International Journal of Hospitality Management, 31, 1021- 1029.

Yaylı, A. (2000), Doğrudan Pazarlama Aracı Olarak İnternet: Konaklama İşletmeciliği Örneği. Pazarlama Dünyası, 14(79): 36-40.

W3C (2008). Web Content Accessibility Guidelines. W3C Recommendation, "https://www.w3.org/TR/WCAG20/", (Son Erişim Tarihi: 10.11.2019). 